\title{
Introduction to Objectives of the United States Foreign Policy
}

IAPSS Think Tank

Working Group 1 : Chander Busham NAGAR, Per HELBERG, Fanny POTKIN

\section{Introduction}

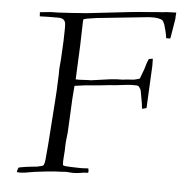

oreign policy of any country is not simply an assemblage of the

policy statements of a country, but it also refers to the commitments, the current form of interests, aims and objectives of a government. Thus, in order to understand the foreign policy of any government it becomes vital to understand the country's national interests and the strategies adopted to achieve it. It has already been proved several times that no government is able to formulate its foreign policy on a clean slate, its policy is always conditioned by its past circumstances.

The case of United States of America is much similar to those of the India's foreign policy in the first quarter of its independence. The first prime minister of India Pt. Jawahar Lal Nehru, has himself drawn parallel and former Ambassador of the United States of America, Chester Bowles has given his view that India's policy is practically indistinguishable from the foreign policy of the United States from 1787 to 1937. The United States won its independence in an un-crowded world that had not yet entered the industrial revolution. There were no great discrepancies in national wealth and the United States (U.S.) was essentially self sufficient. As like the case of colonial India, it engaged extensively in foreign commerce, but its own resources enabled it to do so advantageously and it enjoyed a high relative standard of living.

The fundamental principles of United States foreign policy have been stated in general terms on numerable number of occasions. Some of the statements are general in nature. Some of them were quite relevant from the various point of views. An important view in this regard is to study the history of United States Diplomacy. By going through the various texts we can reach to this conviction that there are certain underlying concepts and principles which had played an important part in U.S. foreign policy throughout all, or most of the history of the United States.

The most basic fundamentals of the U.S. foreign policy are those of the "Security expansion and neutrality". The other view quotes some of the fixed points in the U.S. 
foreign policy like isolationism, the Monroe Doctrine, freedom of seas and the open door policy".1 Another view held the following principles like (i) Sovereign independence, (ii) Continental Expansion, (iii) Avoidance of the ordinary vicissitudes and ordinary combinations, and collisions of the European politics, (iv) the neocolonization principle, (v) the nontransfer principle especially in case of no transfer by one European power to another of any possession in the Western Hemisphere, (vi) Freedom of the seas for neutral ships in time of war and freedom of navigation of the international rivers, (ix) the right of expatriation and the wrong of imprisonment ( $\mathrm{x}$ ) a feeling of antiimperialism2.

The geographical factor also plays an important role in the U.S. foreign policy. The presence on its western side of a continent that was relatively sparse and whose primitive inhabitants were no military match for a modern state. This fact invited a policy of expansion that transcends the frontiers of the United States borders. It has been stated that "the Americans possessed a choosen country with room enough for their descendents to the thousanth and thousandth generations. The theme of the protection of the U.S. sea-based trade also forms a vital significance in the U.S. foreign policy. This theme appears in negotiations for commercial privileges like concerns over rights of Mississippi navigation ports, Spanish New orlean, a problem posed by the British impressments of seaman \& neutral rights. Another aspect of the U.S. fundamental in matter of foreign policy is the American drive for continental expansion, which found expressions in three major military campaigns against the Western American Indian's between 1790 and 1794. Under this previow, the difference in geographical surroundings, this fundamental has no parallel text in India's case.

In the matter of peace and war, the foreign policy matters of the United States, as is being considered it as an alternative means of pursuing the independence voiced the hope, that the U.S. may hope to become an arbiter of Europe in America and to be able to incline the balance of European competition in the part of the world as the national interest may dictate. The determined renunciation of war as a means of achieving foreign policy is unmatched in the history of the United States foreign policy3.

\section{The Course of the Postwar Foreign Policy of the United States}

Before World War - II the United States had only intermittently played a vital role in the World affairs. It emerged from the second world war as one of the super power. Much of the U.S. post world War - 
II policy had centered around her efforts to adjust her view position and to the realities of the post war world. In the post war years the U.S. entered into forming military alliances with old friends in Western Europe and Latin America and with new friends in Asia, nevertheless all of the alliance had been subject to increasing stress. As a matter of fact, the unsatisfactory state of relations between communist and non-communist states, the postwar era had been projected as an era of conflict 4 .

By the year 1946, the United States began to show signs of awakening to the nature of Soviet threat and heading toward a new dimension of foreign policy. The new departure in the foreign policy was stated on 12 March 1947, when the U.S. President George Truman delivered his famous 'Truman doctrine, Speech. In the speech he stated the 'containment of Soviet Union as a prime objective of the U.S. foreign policy5.

\section{India's Foreign Policy Objectives and} U.S. :

India became a full fledged international personality after the attainment of its independence on 15 Aug. 1947. The interim government of the independent India was formed on 2nd Sept., 1946. Before, this date, the external relations of India were conducted by British governing bodies. India attained the very first recognition at international level after joining the league of nations in 1919. India also participated in the San Francisco Conference in 1945 and signed the Charter of United Nations. Another important milestone in same path of progress was the convening the Asian Relations Conference in New Delhi from 23 March to 2 April 1947. Asia after a long period of quiescence suddenly became vital in world affairs. This was the major basis of Pt. Jawaharlal Nehru's perception of Asia in the early years of India's independence. The temper of the Asian Relations conference was set by Pt. Nehru in his inaugural address. His address continues four major elements. Firstly, he proclaimed India's entry in the global scene. Second, he emphasized the need for Asian Unity. Thirdly, he called for avoiding expression of anti-western sentiments. Finally, he attached considerable importance to the imperative of greater regional cooperation6.

When India became free on 15 Aug, 1947, the Indian National Congress, became a center of power with Pt. Jawaharlal Nehru as the first Prime Minister of India. Pt. Nehru was the architect of India's foreign policy and his influence was overwhelming in the formulation of policies objectives. The governing considerations in Pt. Nehru's view in regard to foreign policies are three :

a. The newly independent countries inclusive of India, must not be 
used as pawns by the other states for their personal interests. They must have a free hold in deciding about themselves.

b. There was urgent need to provide a fair and equitable social and economic foundation for our newly formed democracy.

c. There was a need for the maintenance of the territorial integrity of India7.

The Congress first outlived the foreign policy of free India in the Jaipur session of the Indian National Congress in Dec, 1948. The resolution on foreign policy adopted at Jaipur stated that, " the foreign policy of India must necessarily be based on the principles that have guided the congress in the past. These principles are the promotion of world peace, the freedom of nations, racial equality and the ending of imperialism and colonialism. In particular, the Congress emphasized on the freedom of the nations of Asia and African continents, who have suffered under various forms of colonialism for many generations8. The speeches of Pt. Nehru presents a clear cut thought of his in regard to India's foreign policy objectives. In a speech broadcast to the nation on 7th Sept, 1946 he quoted, "We propose as far as possible, to keep away from the power politics of groups, aligned against one another, which have led in the past to world wars and which may again lead to disasters on an even vaster scale. We believe that peace and freedom are indivisible and the denial of freedom anywhere must endanger freedom elsewhere and lead to conflicts and wars. We are particularly interested in the emancipation of colonial and dependent countries and people and in the recognition in theory and practice of equal opportunities for all races. India seek no domination over others and we claim no privileged position over people. But it do claim equal and honourable treatment for our people wherever they may go and we cannot accept any discrimination against them9".

Pt. Jawaharlal Nehru was fully aware of the main task of India's foreign policy, that is the promotion of its national interest. During his speeches he felt the supreme need for peace in building up a new India. As the circumstances of our country were not favourable at the time of independence. In view of the interdependent world, he felt that trouble anywhere in the world would influence India's plan for building up its economy. $\mathrm{He}$ was anxious to maintain friendly relations with all the neighbours in Asia and to cooperate with them in international affair. By the time of independence, the "Cold War"10 and had already started. The polarization of a large part of the world into the Soviet block and Western block led by United States of 
America had taken shape. In view of this India decided to keep away from the politics of alignment.

In the interest of economic development of India, for maintaining the independence of action in foreign affairs for safeguarding the security of nation and for working effectively for world peace, India decided to keep away from the rival power blocks and followed an independent foreign policy. In a speech being delivered at Indian Council of World Affairs, New Delhi on 23 March 1949, Pt. Nehru stated When I say that we should not align ourselves with any power block, obviously it does not mean that we should not be closer in our relation with some countries in comparison to a few other one. At the present moment, you will see that as a matter of fact we have for closer relations with some countries of West, then with others. The closer relation will no doubt developed and we will encourage them to develop11." The following quotations of Pt. Nehru's speech clearly indicate one thing, that both the blocks were having a great expectations in regard to India's stand on foreign policy matters just after the independence. Secondly, it also revealed the India's important geostrategic position in Asia.

The foreign policy makers of India set out certain so as to lay down basic principles to formulate the policy upto a full fledged level. Several of these objectives were common by nature. A former foreign secretary of India, Muchkund Dubey stated that "The primary purpose of any country's foreign policy is to promote its national interest, to ensure its security, safeguard its sovereignty, contribute to its growth and prosperity, further, generally enhance its stature, influence and role in the comity of nations. A country's foreign policy should also be able to serve the broader purpose of promoting peace, disarmament, development and of establishing a stable, fair and equitable global order"12. According to him, the goals of India's foreign policy are simple and straight forward. The primary and overriding goal has always been the maintenance and promotion of international peace and security. The objectives by nature are fundamental and generally accepted by the people13.

India immediately after independence had to determine its policy objectives under difficult circumstances. Internally, the partition of India and creation of Pakistan had left a deep wound of hatred and ill will. Before partition, India was till than one economic unit. The division of economic assets had created many economic problems, with the most challenging one was not very comfortable with the advent of cold war posture. It was in this situation, that India decided that the world peace would be a 
cardinal feature of India's foreign Policy. Peace meant not only avoidance of war, but also reduction of tension prevailing in view of cold war. India had joined the league of nations earlier and also supported the creation of United Nations for the attainment of such cause.

A related objective was to root out the case of war by measures such as liberation of subject people and the elimination of racial discrimination. In order to follow this goal, India decided to follow an independent foreign policy. Thus, the pursuit of peace became a vital aspect in the foreign policy declaration. Pt Jawaharlal Nehru always quoted Mahatma Gandhi's teaching as a basis for foreign policy formulation. $\mathrm{He}$ once quoted in the United States, "Gandhian ethics was the cornerstone of India's foreign policy'. He insisted that physical force need not necessarily be the arbiter of man's destiny and that the method of waging a struggle and the way of termination are of paramount significance14.

Another vital objective of foreign policy was "Elimination of Disease and Illetracy". These are ills not only of Indian society, but also of most of the developing countries of Aisa and African continent. Whereas India's domestic policy was aimed at the removal of these diseases, it was closely related with the question of foreign aid and assistance. India had preferably chosen to cooperate with several international agencies like W.H.O., UNICEF, UNESCO etc. for the betterment of these causes. India voluntarily chose to remain a members of the Commonwealth of Nations. It is the association of free and sovereign countries who were colonies in the esstwhile British Empire now recognises the British Queen only as Head of the Commonwealth, not as crown of Republics like India. Before 1949, only. The Bristish Dominions were members of, what was then known as British commonwealth, All the dominions had the British Crown as their monarch also. India decided not to leave the commonwealth even after it decided to become a republic and censed to accept the British monarch as the head of the state. India owed, along with some other countries, common allegiance to a particular way of life. India considered the continued cooperation with the common wealth of mutual benefit to India and all other member countries 15 .

\section{U.S. Concern Over India's Independence}

\section{\& Before :}

In the struggle of independence, India has drawn inspiration from the United States. The U.S. was the first colonized country to get freedom from bi-imperialism and as such became a modal of emulation. In this background and because of the shared democratic values, it was expected that the Indo-U.S. relations would acquire a 
pattern of positive relationship. Whatever the United States perceptions in the early period of India's Independence, she occupied a special place in their concept of world affairs. Because of this fact United States realized that India was the only country in the Asian Region which was deeply committed to the democratic principles and had the determination, will and also the capacity to progress. India and U.S., though wide apart geographically have been intimately connected by the fact, that both are the largest democracies of the world.

The Indo-U.S. relations date back to the times when the Britishers were here and India was still engaged in her war of independence prior to the decade of twenties. The contact between the people of two nations was limited only to the missionaries and trade. The commercial contacts with India date back from the period immediately following the American revolution, when enterprising merchants in colonial America seeking new fields of commercial enterprises and finding the markets of Europe largely closed to them. Trade with India began to increase again in the early 20th century and it had of course expanded greatly in the post-independence period of India, but the number of consular establishment in India had never been so great as it was during the 1850's. Until 1906, American consular representatives in India and elsewhere were political, appointees, since then they had been career officials and since 1924, they had been regular part of the foreign services of the early starting avenue between the India and United States foreign relations.

During 1865 and 1940, American missionaries played a dominant role in the early relations between U.S. and the Indian Sub-continent. The American missionary came to India in the early part of the 19th century, but there were relatively few of them, prior to the American war of independence. After 1865, their number increased rapidly and Indian sub-continent became the major field of American missionaries enterprise. In general, the American missionaries had not only been the largest single group of Americans in India, but they have also had the most intimate contacts with Indian and have probably made the greatest impact on Indian philosophies and literature16.

During the era of Indian Struggle for independence, the American intellectual, the politicians and the press were quite sympathetic to the Indian National freedom struggle, that some of them were critical of British rule in India. The U.S. president Franklin Delano Roosevelt was sympathetic to the Indian national freedom struggle. The U.S. Senator Blaine's resolution on July 
17,1930 expressed support for the Indian national movement.

The Indian opinion sought the American intervention in their efforts in the struggle for the attainment of independence. Mahatma Gandhi wrote a letter to the U.S. president Roosevelt on 1 July, 1942 appealing him to help the Indian cause. He quoted, "both the India and U.S. believe in knowledge and righteousness, and must make common cause to fight war for the common enemy of our countries17". The U.S. President Roosevelt forwarded America's moral support by sending two special envoys colonel Louis Johnson and William Philips. William Philips in his suggestions, advised the President to press for India's freedom struggle to her excellency of England. On 14 May 1943, he wrote to the president by assuming that India is known to be an important base for the U.S. future operations against Burma and Japan. It would seems to be of highest importance that the U.S. should have around itself a sympathetic India rather than, an indifferent and hostile nation18. Nevertheless, On the occassion of the Quit India Movement, the Indian offer of the wartime collaboration in exchange of the political concessions was viewed by the U.S. as a feeling of blackmail. The U.S. was not prepared to perceive the Indian demand. Yet, the then U.S. secretary of state Sunner Wells stated, that if the Indian struggle is in fact a war for the liberation of its peoples, it must assure the sovereign equality of the people though out the world. The U.S. leadership perceives this demand in somewhat substantive way. The future gains from India always dominant in the U.S. policy towards India.

The U.S. Senate foreign Relations committee also took a firm stand. It stated the demand that India might be given a status of autonomy. It further stated, the only way to get the people of India to fight is to get them to fight for India. The committee demanded a status of autonomy for India19.

During the period of intense negotiations for partitioning the country, the United States closely followed the Indian situation and was the only country to receive advance briefing from England. Ultimately, when it found, the partition to be inevitable, it gave up its mediatory efforts, lest this should be misunderstood to be taking sides and thereby jeopardize ties with the successor countries India and Pakistant 20.

The first prime minister of independent India Pandit Jawaharlal Nehru was conscious of the importance of the United States, while drawing the resolution for the All India Congress Committee in 1952, he stated that "the next 100 years are going to be the country of America". As a growing power, the United States is un- 
doubtly going to play a very major role in the years and generations to come21.

In India, even before the transfer of power, while there as an interim government was in the power, India was informed by the U.S. Secretary of State Lord Byrns that United States would be happy to receive Sir Girija Shankar Vajpayee as Charg. D. Affairs, the appointment of an Indian Ambassador in Washington D.C., the state capital of the United States of America. On April 10, four months before India's independence, Henry F. Grady was appointed the first American Ambassador to India. He presented his letter of credence on 1 July 1947. He expressed the belief that in the context of the cold war it would be better for India to be on he Western bloc. This feeling of the United States formed a sympathetic turn in its perception towards India. In the initials phase of India's dealing in the international affairs, Pt. Nehru called an international conference on Indonesia. India also decided to remain as a part of Common Wealth Association. The withdrawal of the French and the Dutch from the South East Asian region, the emergence of Communist China and India's sympathetic attitude towards her, made a sense of vacuum being created in the bilateral relations between India and U.S. It could only be pervasive for India to play a leading role in this area. India seen as an unparalleled opportunity for the United
States to make up a lost ground in South Asia22.

In order to cover the new emerging vacuum in the relations, the U.S. invited Pt. Nehru to visit the U.S. He made an official visit in 1949. Pt. Nehru received a warm welcome from the government and the people of the United States. Addressing a joint session of the House of Representatives and the Senate, Pt. Nehru recalled the "declaration of independence" which greatly influenced him and the Indian Constitution. He States, "I have come to United States, on a voyage of discovery of the mind and heart of America and to place before the American, our heart and mind". Pt. Nehru in this manner describes his visit as "Discovery of America"23. At this time, the United States was favourably disposed towards India. Although, some basic differences inherent by nature and a conflict in opinion had started cropping up the issues of foreign policy on world problems like colonialism, communism, disarmament, Kashmir issue etc.24. The first ever differences in opinion came to light with the Indian support over the Chinese admission to United Nation (U.N.) and the U.S. perceive, this as 'timid', short sighted an irresponsible step25. In a similar other move, Indian opinion outraged at the indiscriminate bombings in South Korea. The Institute of Pacific Relations Organized a conference at Lucknow in Oct. 1950, in its 
report it lamented American action and consequently, India remain apart on the resolution, authorizing the U.S. Army General Mc. Aurthor to head the U.N. force to intervene in Korean crisis. This was much resented by the Americans, who were irritated by this attitude of the Indian leadership26.

\section{References :}

1. Nathaneil Peffer has quoted these policies as the basis of U.S. foreign policy. Norman D. Palmer, Haward C. Perkins, "The foreign policy of the United States" Scientific Book agency, Calcutta, 1970, P. 646647.

2. ibid. P. 646-647.

3. Edwin. C. Hyot, "Foreign Policies of India and U.S., A Comparison.” P. 161.

4. Palmar and Perkins, "International Relations". CBS Publishers, Delhi, P. 651-252.

5. ibid. P. 654- 655.

6. The Asian Relations conference comprise of major themes like (i) National Liberation movement, (ii) Racial problem, (iii) Issue o migration, (iv) Transition from colonial to National economy, (v) Agriculture \& industry (vi) Labor issues, (vii) Cultural Affairs, (viii) Status of women, Harcharan Singh Josh, "India's Foreign Policy, Nehru to Rao (N. Delhi - 1994) P. 12-13

7. Sisodia S.S., "Foreign Policy of India, Indira Gandhi Era”. (Inter, India Publications, New Delhi 1985) P. 7.

8. N.V. Rajkumar, "The Background of India's Foreign Policy". (N.Delhi 1952) P. 59.

9. opcit. Sisodia, P. 2.

10. Cold war defines as a phase of hostile relations between U.S.S.R. and U.S.A. in which no direct war occurred. There were policy criticisms occurred rather than direct use of weapons as means.

11. opcit. Sisodia, P. 4.

12. Muckhand Dubey, 'India's Foreign policy in the evolving Global order in International Studies”, April -June 1993. P.117.

13. ibid. P. 117 
14. J. Nehru, "Inside America", New Delhi. P. 34.

15. Mahendra Kumar, "India's Foreign Policy”.

16. The writings of the Indian philospher like Raja Ram Mohan Raj deeply influenced by the thoughts of the American missionaries. Vadilal Dagli, “ Two decades of Indo-U.S. Relation”. Vohra \& Comp. Publishers, 1969, P. 160.

17. The Hindustan Times, 22 June 1960.

18. ibid.

19. Kamath, "The United States and India”. P. 128.

20. R.C. Joshi, " The American Effort to Avert the Impending Partition of India 1946-47”.
Indian Journal of Asian Studies, July 1978, Vol. 18, No.2.

21. opcit. Kamat, P. 208.

22. New York Times, 31 Aug, 1949.

23. J.L. Nehru, "India's Foreign Policy, Selected Speeches". Sept1946- April 1961, Publication Division, Govt. of India, N. Delhi, 1961, P.589.

24. All issues are generally debatable except the Kashmir dispute. As Pakistan has joined the South East Asian Treaty Organization (SEATO), thus obviously got a favour from the United States.

25. New York Times, 12 Oct, 1950. 